\title{
COMPARISON OF SAND BURIAL-DEPENDENT GROWTH RESPONSES OF TWO TRA- GOPOGON SPECIES FROM DIFFERENT HABITATS
}

\author{
Gederts IEvinSH*, Kristīne K. LeJNIECE
}

University of Latvia, Faculty of Biology, Department of Plant Physiology, Jelgavas Str. 1, 1004 Rīga, Latvia *Corresponding author. E-mail: gederts.ievins@lu.lv

\begin{abstract}
Ievinsh G., Lejniece K.K., 2021: Comparison of sand burial-dependent growth responses of two Tragopogon species from different habitats. - Botanica, 27(1): 13-22.

Wind-driven sand movement leading to sand burial is an essential environmental factor in coastal sand dunes; therefore, plants native to sand dunes need to possess specific adaptations. The present study aimed to compare responses to variable sand burial intensity of Tragopogon heterospermus, rare plant species native to coastal dunes, and Tragopogon pratensis taxonomically related grassland species. Plants in culture were established from seeds collected in natural habitats, cultivated in an automated greenhouse, and individuals of different age were buried by sand in the different depths. Both plants had basic sand burial tolerance, seen as an elongation of adult plants' leaf bases under moderate sand burial conditions. However, only dune-adapted T. heterospermus plants exhibited efficient resource allocation from roots to shoots with increased sand accretion intensity. T. heterospermus plants had pronounced age dependence of burial tolerance, with higher sensitivity to sand burial at an earlier stage due to small shoot height and, possibly, certain physiological factors.
\end{abstract}

Keywords: coastal dunes, growth response, sand burial, Tragopogon heterospermus, Tragopogon pratensis.

\section{INTRODUCTION}

Wind-driven sand movement leading to both sand accretion and sand erosion is an important environmental factor in coastal dunes, affecting both species distribution and their physiological status (LEE \& IGnaciuk, 1985; Maun \& Perumal, 1999; Isermann, 2011; Dech \& Maun, 2005; KeiJsers et al., 2015). The open dune species' ability to successfully grow and reproduce under the influence of sand burial is related to specific adaptations at the morphological and physiological level (HESP, 1991; IEvinsh, 2006). However, even within the same sand-affected habitat type, the degree of particular species' adaptivity to sand burial can differ significantly. Thus, while several dune-building plants such as Ammophila arenaria (L.) Link, Honckenya peploides (L.) Ehrh., Leymus arenarius (L.) Hochst., Leymus mollis (Trin.) Pilg, Uniola paniculata L., can be designated as burial-dependent species (GAGNÉ \& Houle, 2002; Gormally \& Donovan, 2010), other characteristic sand dune species (Alyssum montanum subsp. gmelinii (Jord.) Hegi \& Em.Schmid) can only tolerate moderate degree of sand accretion (SAMSONE et al., 2010).

Response to sand burial is a complex and highly dynamic biological process, which involves different structural organisation levels and various mechanisms, from the perception of the environmental signals to hormonal regulation, gene expression and resulting metabolic and morphological changes (MAUn, 1998). An ecologically significant feature of plants regarding sand burial is related to changes with the individual's ontogenetic phase in the degree of tolerance and type of responses. Usually, seedlings and smaller young plants are less tolerant to sand accretion (Li et al., 2010); therefore, not only intensity, but also timing of the burial episode in respect to the 
developmental stage is essential. One of the physiological mechanisms related to sand burial tolerance is associated with resource redistribution among plant organs, related to the ability to grow out of the layer of deposited sand. In a situation of sand accumulation, when the decrease of leaf area available for photosynthesis significantly limits the amount of carbon fixed for immediate needs of growth maintenance (Kent et al., 2005; Qu et al., 2017), root growth is arrested, and carbohydrate reserves stored in roots are directed towards support for elongation of specific aboveground plant parts (GILBERT \& Ripley, 2008).

Tragopogon heterospermus Schweigg. is an endemic species of the south-eastern coast of the Baltic Sea (Del Vecchio et al., 2017), where it is an umbrella species of the European protected habitat EUH 1230 "Vegetated sea cliffs of the Atlantic and Baltic coasts" (Rēriha, 2013), and is an essential component of the European protected habitat EUH 2120 "Shifting dunes along the shoreline with Ammophila arenaria (white dunes)" (LAIME, 2013). Mycorrhizal status of T. heterospermus in coastal sand dunes has been confirmed, showing Arum-type morphology and presence of lipid bodies in vesicles, with 8 to $23 \%$ of symbiotic intensity in roots of plants from different sites (Druva-Lusite \& IEvinsh, 2010). Based on characteristic location on a top of the dune ridge, $T$. heterospermus is listed among species not tolerating sand accretion (URBONIENE et al., 2015). However, no studies can be found in the scientific literature regarding the ecology or physiology of the species. Still, due to its abundant presence in dune habitats with different degree of sand fixation, at least moderate tolerance to the sand burial of the species could be proposed.

Tragopogon pratensis $\mathrm{L}$. is an umbrella species of the European protected habitat EUH 6510 "Lowland hay meadows (Alopecurus pratensis, Sanguisorba officinalis)" (RŪsIN̦A, 2013). Ecology and physiology of generative propagation of $T$. pratensis have been relatively widely investigated because of the importance of the species as a weed (QI et al., 1996) and is a significant vegetation component of dry grasslands, not forming persistent seed bank (JORRITSMAWIENK et al., 2007). Aspects of seedling establishment from seeds have been studied in T. pratensis, including seed anaerobiosis, storage temperature, and sowing depth (Di \& Upadhyaya, 1993). Seeds of $T$. pratensis germinated even at the 14-cm-burial, but emergence decreased with the increase of burial depth to more than $2 \mathrm{~cm}$, and no seedlings emerged from 8-cm-buried seeds. Consequently, no specific physiological adaptation of the species to sand burial could be proposed. According to molecular analysis data, T. heterospermus and T. pratensis are closely related species within the genus Tragopogon (MAvRODIEV et al., 2008).

The present study aimed to compare responses to variable sand burial intensity of $T$. heterospermus and $T$. pratensis plants of different age. The hypothesis tested was that $T$. heterospermus plants from a coastal dune habitat with a certain persistent degree of sand accretion during vegetation season will have pronounced burial tolerance associated with resource allocation, while $T$. pratensis plants from dry meadow habitat will have no pronounced tolerance to sand burial.

\section{MATERIALS AND METHODS}

\section{Seed source}

Seeds of T. heterospermus were collected in natural sand dune habitat on the Baltic Sea coast near Jūrmalciems and Ziemupe, Latvia, in July 2017. Seeds of T. pratensis were collected on a dry edge of natural wet grassland habitat on the shores of Lake Liepājas in the territory of city Liepāja, Latvia, in July 2017. Seeds were allowed to dry in laboratory conditions for one month and then were stored in paper bags at $4^{\circ} \mathrm{C}$.

\section{Seedling establishment}

For plants' establishment, seeds were surface sterilised with 50\% commercial bleach Ace (Procter \& Gamble) for 7 min followed by extensive rinsing in deionised water (five times for $2 \mathrm{~min}$ ) and imbibed for $4 \mathrm{~h}$ in deionised water. Seeds were sown in $400 \mathrm{~mL}$ plastic containers with a mixture of autoclaved commercial garden soil (Biolan, Finland) and quartz sand $(1: 1, \mathrm{v} / \mathrm{v})$ and placed in a growth cabinet with a thermo-period $15 / 20^{\circ} \mathrm{C}$ (night/day) in conditions of $12 \mathrm{~h}$ photoperiod (photon flux density of photosynthetically active radiation $40 \mu \mathrm{mol} \mathrm{m}^{-2} \mathrm{~s}^{-1}$ ).

When seedlings reached the second leaf stage, they were individually transplanted to square plastic containers $(11 \times 11 \times 12 \mathrm{~cm}, 1.2 \mathrm{~L})$ filled with 
$750 \mathrm{~mL}$ of a mixture of garden soil and quartz sand $(1: 1, v / v)$. Containers were placed on individual plastic plates and located in an experimental automated greenhouse (HortiMax, Netherlands) with supplemented light from Master SON-TPIA Green Power CG T $400 \mathrm{~W}$ (Philips, Netherlands) and Powerstar HQI-BT 400 W/D PRO (Osram, Germany) lamps (380 $\mu \mathrm{mol} \mathrm{m}^{-2} \mathrm{~s}^{-1}$ at the plant level), $16 \mathrm{~h}$ photoperiod, day/night temperature $23 / 15^{\circ} \mathrm{C}$, relative air humidity 60 to $70 \%$. The position of individual plants was randomly changed every week. Soil moisture of plants was monitored with $\mathrm{HH} 2$ moisture meter equipped with WET-2 sensor (Delta-T Devices, UK) on a daily basis, not allowing a decrease of substrate moisture lower than $60 \%$ water holding capacity. Plants were watered from the bottom using equal amounts of deionised water for all treatments. Once a week, plants were fertilised from the bottom of the containers with a Kristalon Green Label fertiliser (NPK 1818-18 with micronutrients; Yara International, Norway) solubilised in deionised water $\left(150 \mathrm{~g} \mathrm{~L}^{-1}\right)$, with $5 \mathrm{~mL}$ of stock solution per $\mathrm{L}, 100 \mathrm{~mL}$ of the final fertiliser per container.

\section{Experimental design}

Four separate experiments were performed with $T$. heterospermus, and two with $T$. pratensis (Table 1). Plants of different age $(8,12,36$, and 64 days for T. heterospermus; and 36 and 64 days for T. pratensis) were individually selected at the appropriate time from a stock material cultivated in a greenhouse and used for sand burial treatment. For experiments with the 64-day-old $T$. heterospermus and $T$. pratensis, plants were replanted to larger containers $(11.3 \times$
$11.3 \times 21.5 \mathrm{~cm}, 2 \mathrm{~L}$ ) containing $750 \mathrm{~mL}$ of the same substrate four days before the treatment. The treatment was performed as a single burial episode, using autoclaved pure quartz sand (Saulkalne S, Latvia). Plants of different age were buried in different depth (Table 1). Relative sand burial intensity was estimated as the per cent of shoot height covered by sand after the burial. Five individual plants were used for burial treatment, except for experiments with the 36and 64-day-old plants of $T$. heterospermus, where ten individuals per burial treatment were used.

Plant growth after sand burial was monitored by assessing shoot height (measured as a length of the longest leaf) regularly after two to four days. Cell elongation at leaf bases was evaluated visually as the appearance of a brighter leaf area. Plants were cultivated in a greenhouse in the same conditions as previously 29 to 50 days after the burial treatment (Table 1). After that, each experiment was terminated. Plants were separated from the substrate, and fresh and dry mass (after drying of tissues to constant mass in an oven at $60^{\circ} \mathrm{C}$ ) was measured. Biomass data were expressed as per cent values relative to unburied control plants. For the 64-day-old $T$. pratensis experiment, plant leaves were divided according to their position in a rosette and size as "old" (outer larger leaves) and "young" (inner smaller leaves), counted and weighed separately.

Data analysis was performed using KaleidaGraph (v. 4.1, Synergy Software). Growth data were analysed by one-way ANOVA, followed by Fisher's LSD test. Student's $t$-test was used to estimate statistically significant differences between individual treatments $(p<0.05)$.

Table 1. Sand burial intensity (expressed as a \% of shoot height covered by sand after the burial) performed in individual experiments in respect to the height of Tragopogon heterospermus and T. pratensis plants at different ages

\begin{tabular}{|c|c|c|c|c|c|c|}
\hline \multirow{2}{*}{ Burial depth $(\mathrm{cm})$} & \multicolumn{4}{|c|}{ T. heterospermus } & \multicolumn{2}{|c|}{ T. pratensis } \\
\hline & 8 days & 12 days & 36 days & 64 days & 36 days & 64 days \\
\hline 1 & - & - & 4.5 & - & 3 & - \\
\hline 2 & 32 & 29 & 9 & - & 6 & - \\
\hline 3 & - & - & $14 \%$ & 8 & 9 & 8 \\
\hline 4 & 63 & 57 & - & - & - & - \\
\hline 6 & - & - & - & 16 & - & 16 \\
\hline 9 & - & - & - & 24 & - & 24 \\
\hline Plant height (mm) & 63.1 & 70.1 & 220.4 & 371.3 & 328.4 & 376.4 \\
\hline $\begin{array}{l}\text { Growth period } \\
\text { after burial (days) }\end{array}$ & 50 & 36 & 38 & 34 & 29 & 40 \\
\hline
\end{tabular}




\section{RESULTS}

The age and height of $T$. heterospermus seedlings at the beginning of sand burial treatment had a significant effect on their burial tolerance. When seedlings were exposed to 2 and $4 \mathrm{~cm}$ sand burial (corresponding to 32 and $63 \%$ of their height) in the early phase of development (eight days), there was no inductive growth response of shoots for $2 \mathrm{~cm}$ treatment, as seedlings continued to grow at the previous rate $(\mathrm{F}=0.63, p=0.43)$, but seedlings in $4 \mathrm{~cm}$
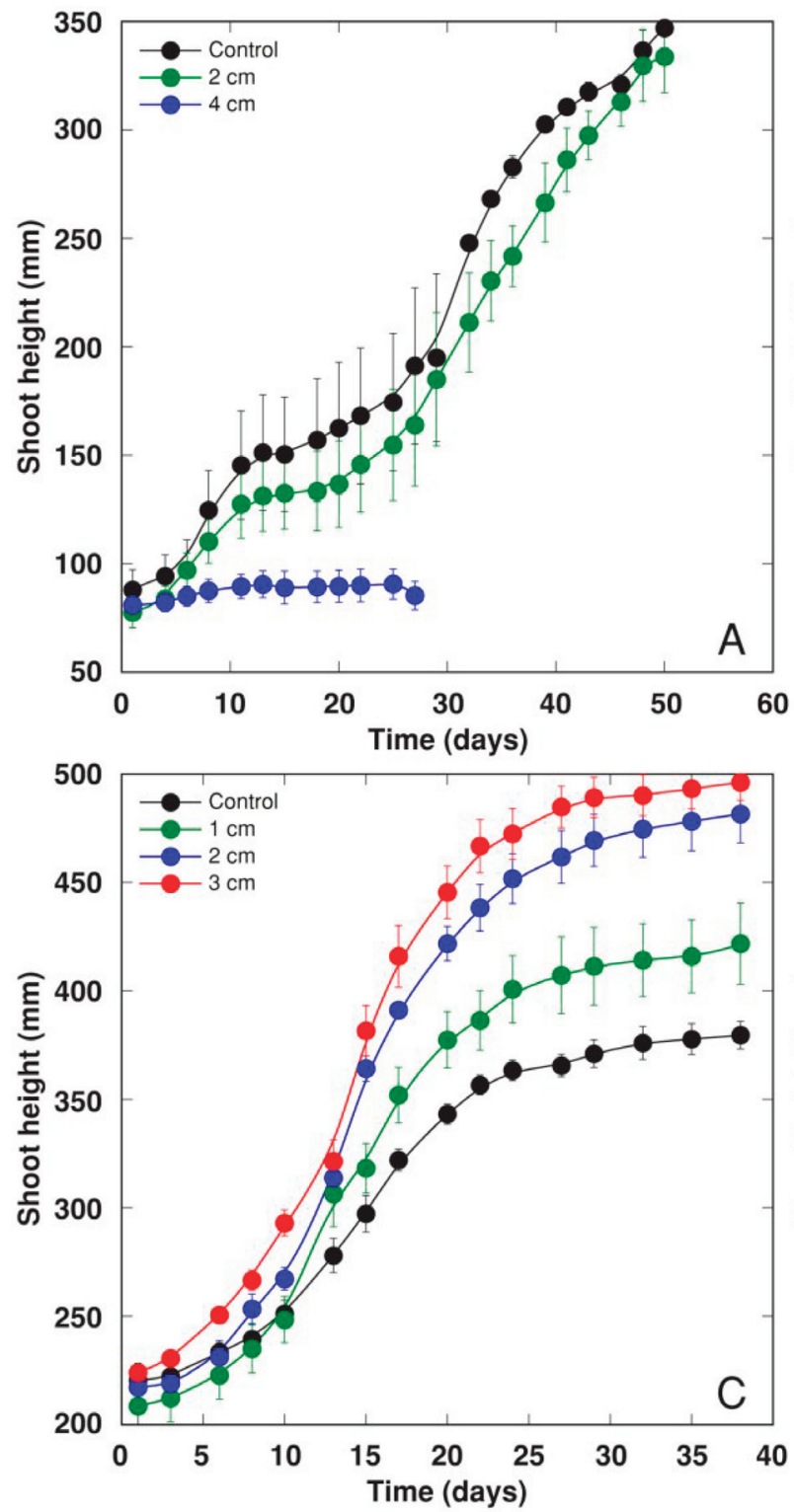

treatment ceased to elongate and eventually died after 27 days (Fig. 1A). When the same burial treatment was performed with the 12-day-old seedlings, plants at both burial intensities showed an increased shoot elongation rate, which initially was more pronounced for $4 \mathrm{~cm}$ treatment (Fig. 1B). Still, the effect was not statistically significant $(\mathrm{F}=0.89, p=0.42$ ). Relatively lower sand burial intensities $(4.5,9$ and $14 \%$ of plant height buried by sand) were used with the 36-day-old $T$. heterospermus plants to find a relationship between the degree of moderate burial and
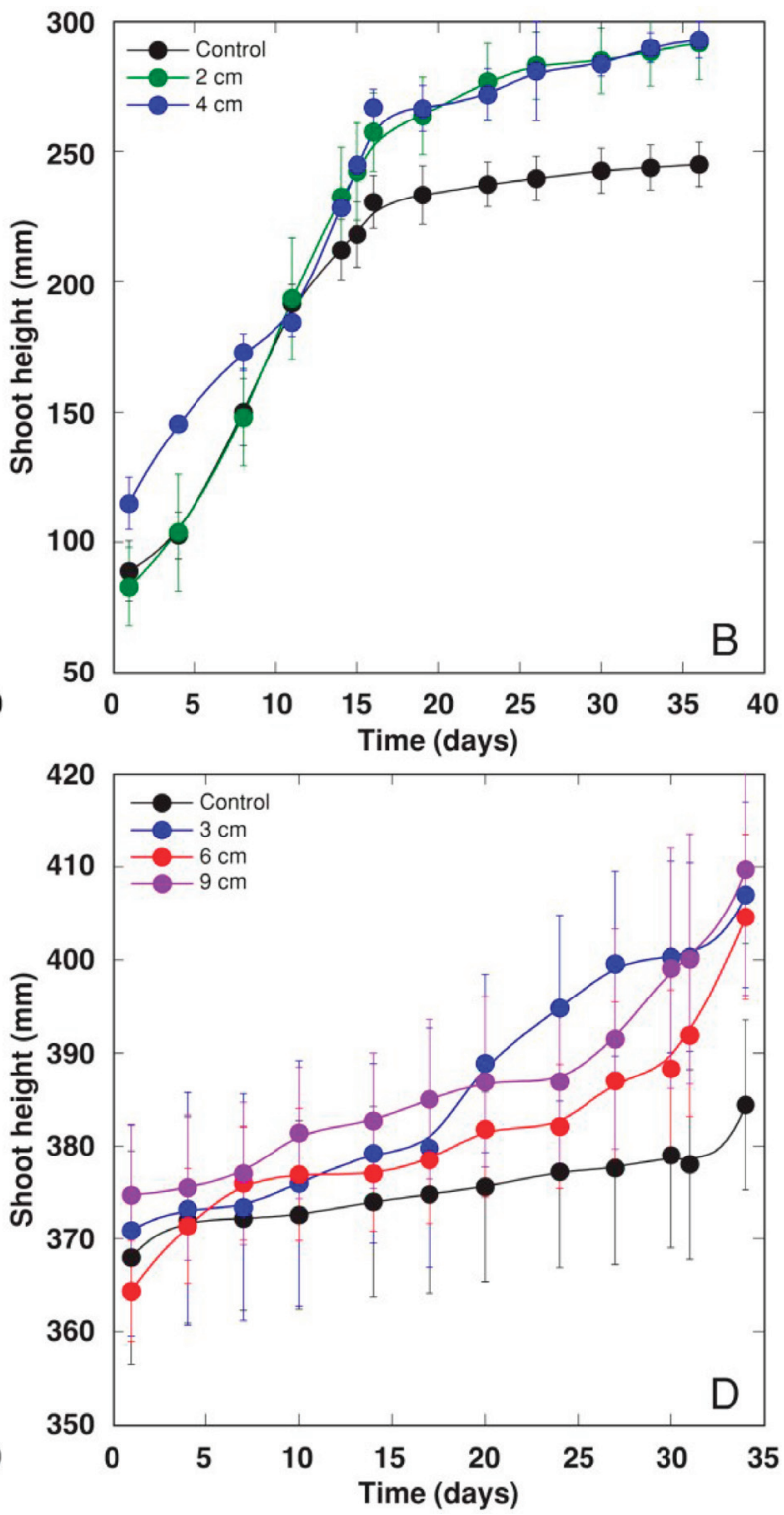

Fig. 1. Shoot height response of the 8-day-old (A), 12-day-old (B), 36-day-old (C) and 64-day-old (D) Tragopogon heterospermus plants following the sand burial at different age. Shoot height is presented as the shoot's summed value above the substrate surface plus the shoot's buried part. Data are means $\pm \mathrm{SE}$ of five replicates for A and B, and ten replicates for C and D 
that of leaf elongation response. This indeed was the case, as the intensity of stimulation of shoot elongation increased with increasing burial depth (Fig. 1C; $\mathrm{F}=3.92, p=0.02$ ). However, the response seemed to be saturable as there was only a negligible difference in plants' shoot growth, between 2 and $3 \mathrm{~cm}$ treatments. In contrast, when the 64-day-old plants were used for burial treatment at relatively higher rates, shoot elongation response was not statistically significant on the dependence of burial intensity (Fig. 1D; $\mathrm{F}=2.37, p=0.08)$.
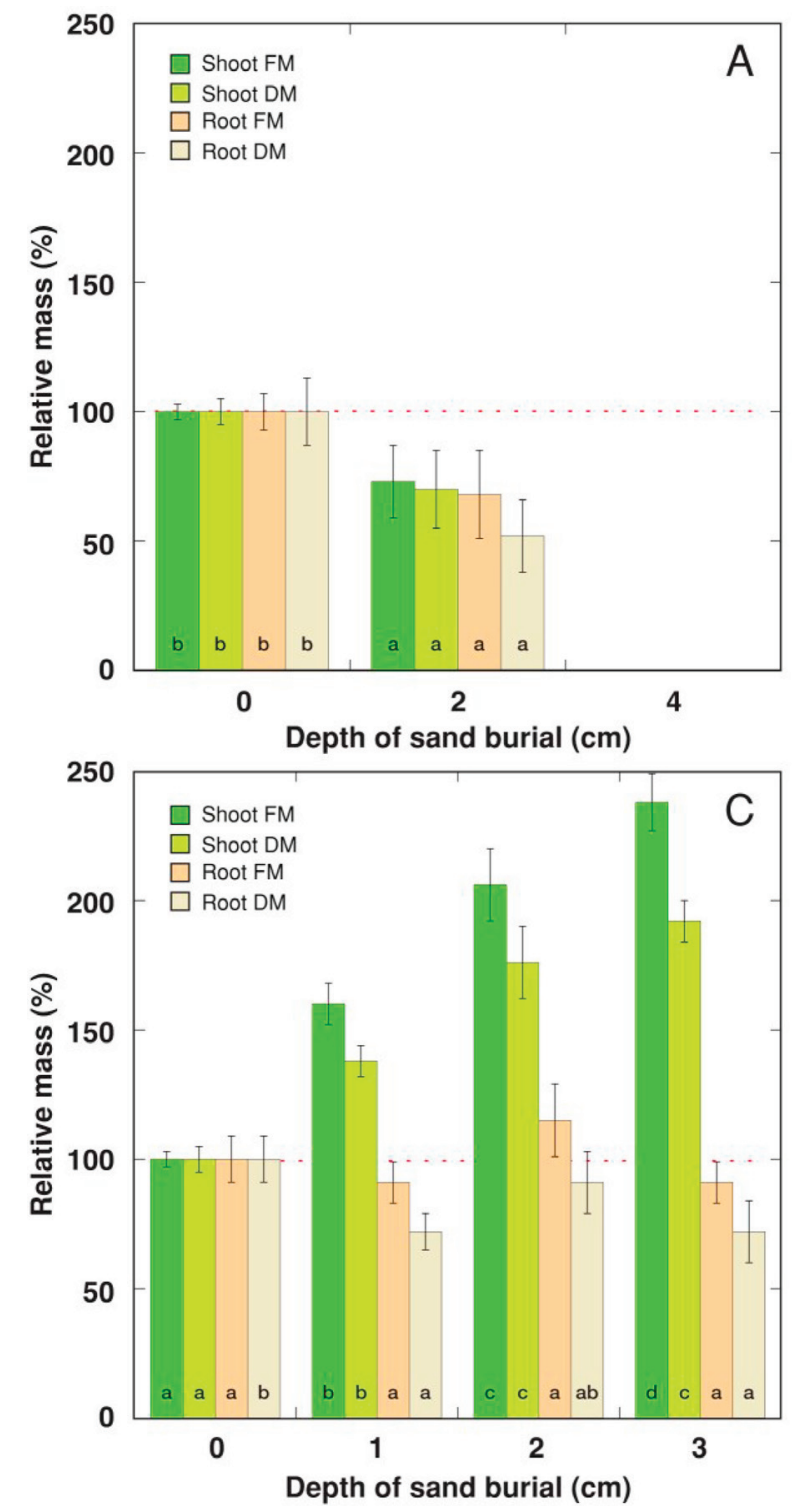

Sand burial at an early stage of seedling development for $T$. heterospermus resulted in significant growth inhibition for both shoots and roots (Fig. 2A). For the 12-day-old seedlings, $2 \mathrm{~cm}$ burial significantly stimulated root growth. Still, in $4 \mathrm{~cm}$ burial, there was a tendency of shoot and root growth inhibition, but the effect was significant only for root dry mass accumulation (Fig. 2B). Moderate burial intensity for the 36-day-old plants resulted in linearly increased shoot biomass accumulation, and there was a tendency for inhibition of root growth. Still, the effect
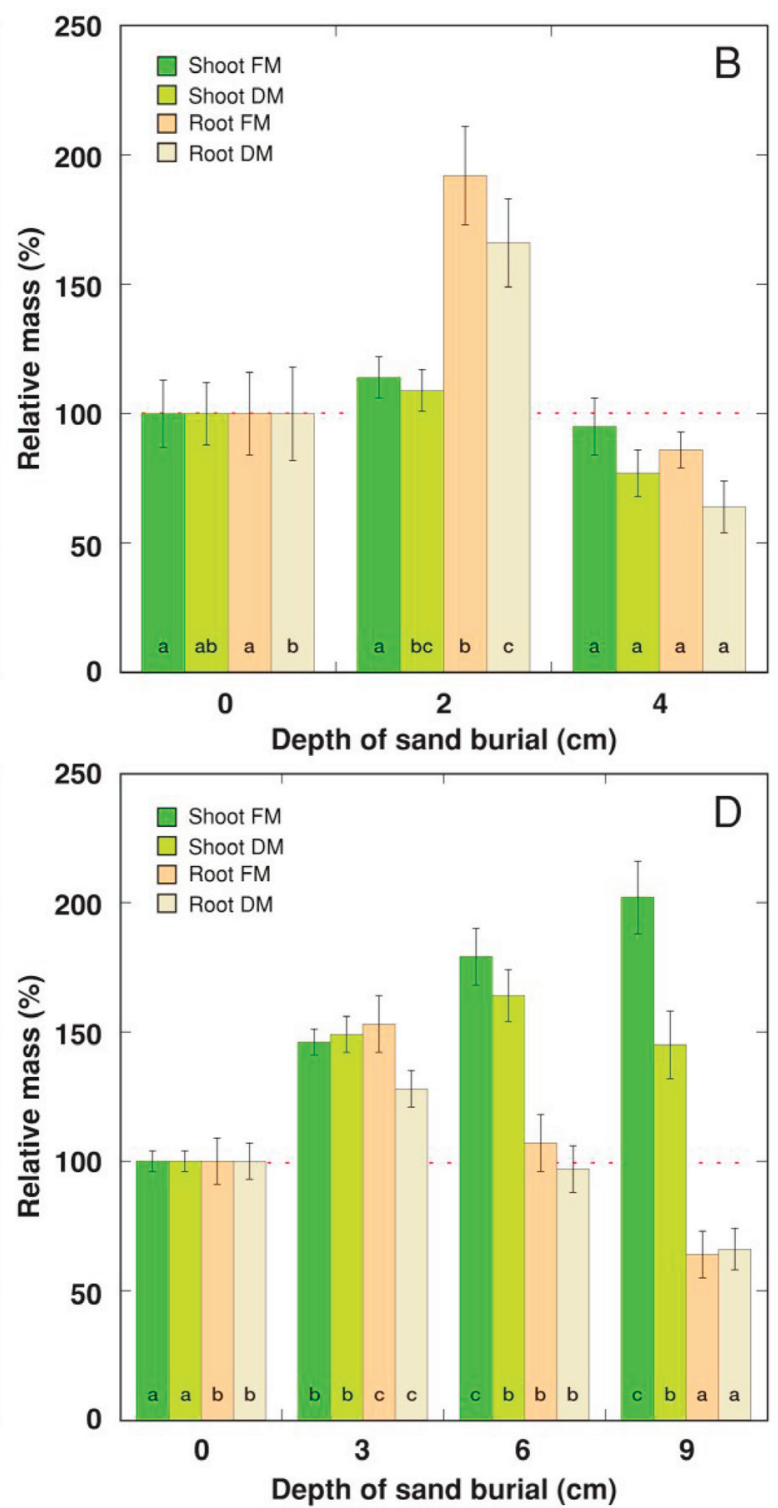

Fig. 2. Shoot and root biomass of Tragopogon heterospermus plants affected by sand burial at different age. A - 8-day-old, B - 12-day-old, C - 36-day-old, D - 64-day-old plants at the time of burial. Data are expressed as per cent values relative to unburied control plants. They are means $\pm \mathrm{SE}$ from five replicates for $\mathrm{A}$ and $\mathrm{B}$, and ten replicates for $\mathrm{C}$ and $\mathrm{D}$. Columns marked with the same letter for the particular parameter are not statistically significantly different $(p<0.05)$ 
was statistically significant only for root dry mass for plants in 1 and $3 \mathrm{~cm}$ treatments (Fig. 2C). Three types of effect were evident for the 64-old-plants depending on burial depth: $3 \mathrm{~cm}$ treatment resulted in significant biomass accumulation in both shoots and roots; in $6 \mathrm{~cm}$ treatment, shoot growth was more pronounced than previously, but there was no significant effect on root growth; and in $9 \mathrm{~cm}$ treatment, shoot growth was significantly stimulated, but root growth was significantly inhibited (Fig. 2D). The elongation growth response of shoots was related to expanding the stimulation of the leaves' basal zone.

Trogopogon pratenesis plants at the 36- and 64day-old were performed according to the same treatment design as $T$. heterospermus of the respective age. The growth response of the 36-day-old plants was not observed within the first ten days after the start of the burial. Within the next 20 days, there was an evident response of shoot elongation depending on the burial intensity (Fig. $3 \mathrm{~A} ; \mathrm{F}=3.55, p=0.04$ ). In contrast, no burial-dependent growth response developed within 20 days for the 64-day-old $T$. pratensis plants (Fig. 3B; $\mathrm{F}=1.11, p=0.36$ ). No growth measurements were performed further as there were no signs of initiation of growth response, but plants were cultivated for additional 23 days.

Sand burial resulted in a significant increase of

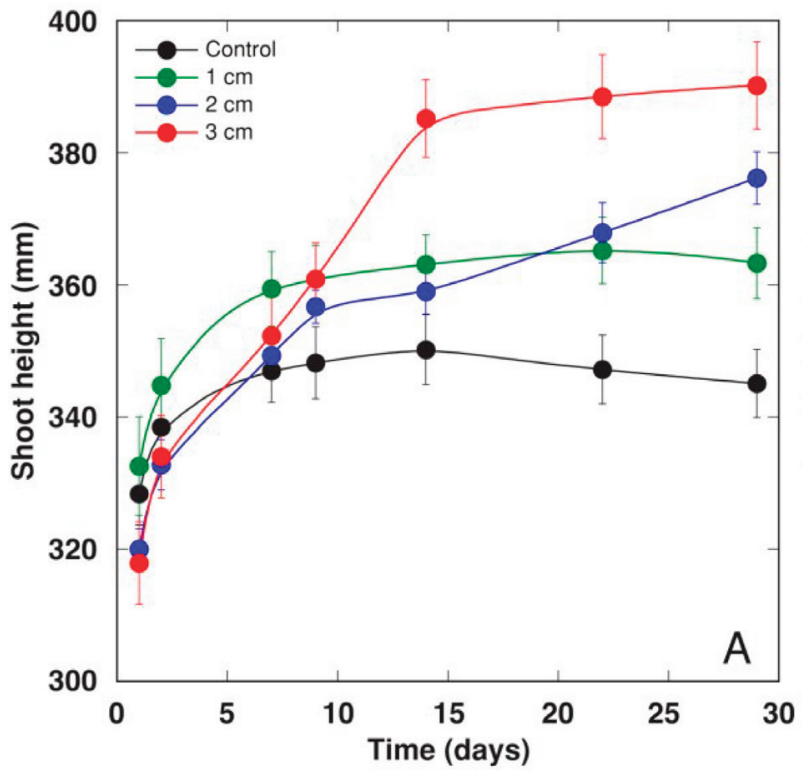

shoot and root biomass for the 36-day-old T. pratensis plants irrespective of burial intensity. Still, the stimulative effect of shoot growth in $3 \mathrm{~cm}$ treatment was significantly higher than that of $2 \mathrm{~cm}$ treatment (Fig. 4A). When the experiment with the 64-day-old plants was terminated after 40 days of the beginning of treatment, it appeared that burial resulted in a significant reduction in the number of older and younger leaves to a similar extent (Fig. 4B). However, the fresh mass of both older and younger leaves increased at $3 \mathrm{~cm}$ burial depth, but only biomass accumulation of younger leaves was significantly stimulated with further increase in burial depth, but biomass of older leaves significantly decrease at $9 \mathrm{~cm}$ burial. The growth response of $T$. pratensis shoots due to burial was also based on the elongation of leaf bases, which was especially pronounced for younger leaves.

\section{DISCUSSION}

It appears that all plant species have at least some level of general sand burial tolerance, as an ability to withstand episodes of being in part covered by sand layer (Gilbert \& Ripley, 2010). However, in the present study, the emphasis was on one particular aspect of survival, possible changes of plant biomass accumulation in above- and below-ground

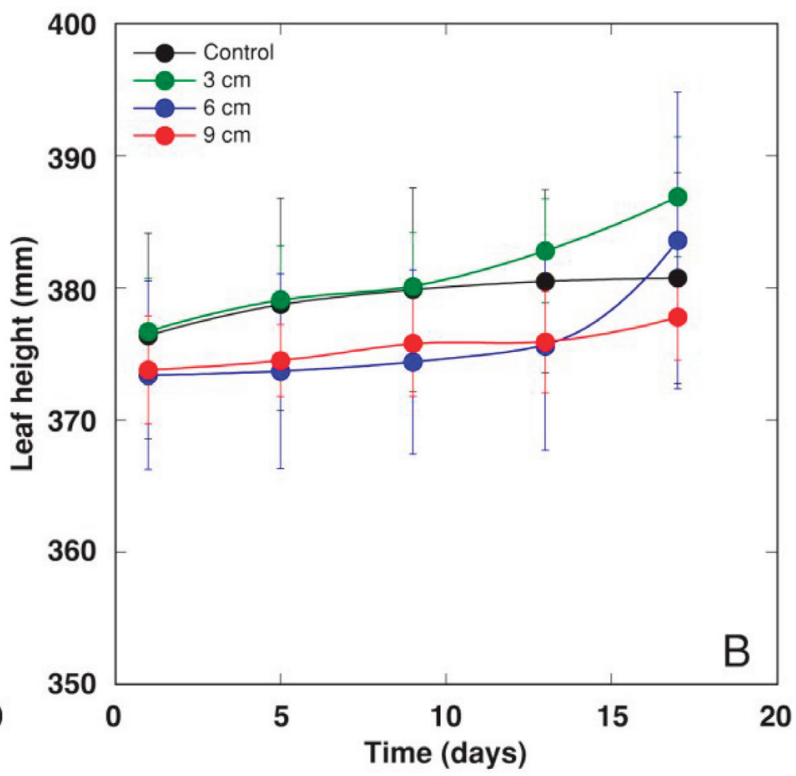

Fig. 3. Shoot length response following sand burial for the 36-day-old (A) and 64-day-old (B) Tragopogon pratensis plants. For the sake of comparison, shoot length is presented as summed value of shoot above substrate surface plus buried part of the shoot. Data are means \pm SE from five individual replicates 

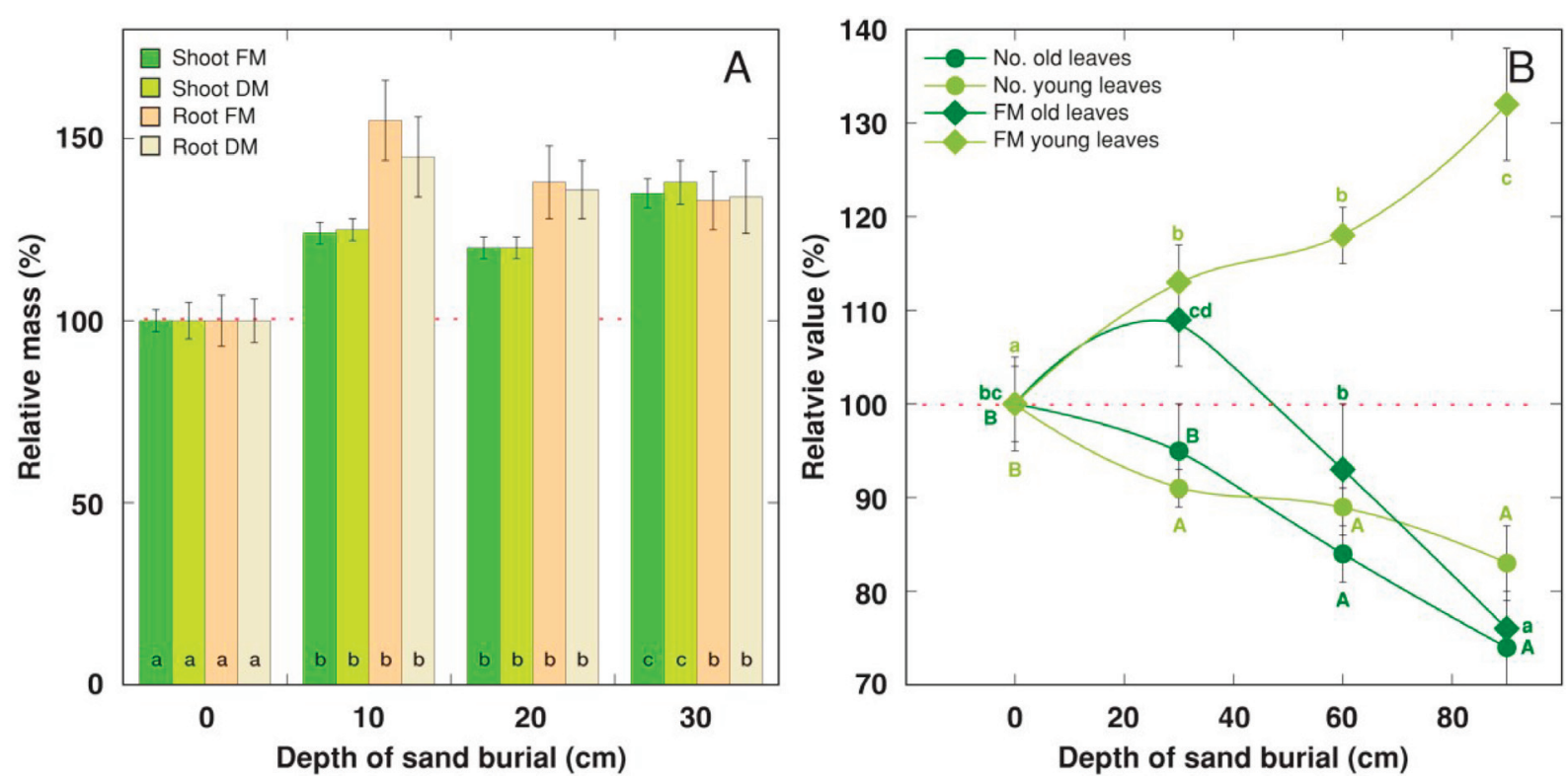

Fig. 4. Changes in shoot and root biomass of the 36-day-old (A) and changes in leaf number and biomass of the 64-day-old (B) Tragopogon pratensis plants affected by sand burial in different depths. Data are expressed as per cent values relative to unburied control plants and are means \pm SE from five individual replicates. Columns or symbols marked with the same letter for the particular parameter are not statistically significantly different $(p<0.05)$

plant parts. While growth inhibition of buried plants is a sign of sensitivity to this environmental factor, shoot growth stimulation due to sand accretion is one of the positive plant responses to burial often associated with tolerance (SYKES \& WiLSON, 1990). This response is an important mechanism to sustain the photosynthetic capacity to survive buried individuals (KENT et al., 2005). However, some tolerant species do not show shoot growth stimulation due to burial (Sykes \& Wilson, 1990). Suppose these plants respond to burial by decreased biomass of roots. In that case, it can be viewed as a tolerance mechanism associated with resource allocation from roots to shoots, but without growth stimulation because of the general scarcity of resources (GILBERT \& Ripley, 2010).

In the present study, $T$. heterospermus from sand dunes, a putative burial-tolerant species, were compared with taxonomically related dry meadow species T. pratensis with no apparent burial tolerance. It was expected to find different responses to the moderate sand burial of the two species. Moderate burial intensity for the 36-day-old plants resulted in pronounced linearly increased shoot biomass accumulation in T. heterospermus with a tendency for decreased root growth (Fig. 2C). Still, in T. pratensis of the same age, both shoot and root growth were slightly stimulated (Fig. 4A). Moreover, while positive shoot growth response had a significant lag phase for the 64-day-old T. heterospermus plants (Fig. 1D), there was no such response regarding $T$. pratensis plants of the same age (Fig. 3B).

When analysing plant responses to sand burial, it is essential to discriminate between plants growing from seeds deposited under a sand layer of different depth and plants for whom burial episode occur at different stages of individual development. In the first case, the seed's energy reserve is a determining factor for the successful emergence of the growing seedling (MAun, 1994). Different morphological and physiological mechanisms are necessary for burial tolerance of already established plants. As it can also be seen from the results of the present study that the age of seedlings or plants is another critical factor to consider in sand burial studies. T. heterospermus plants displayed relatively low tolerance to burial (Fig. 1), as the 8-day-old seedlings did not survive $4 \mathrm{~cm}$ burial by sand. Still, the 12-day-old seedlings did survive and even showed a positive growth response of their shoots. However, burial depth relative to plant shoot height needs to be assessed for better comparison. For younger seedlings, $4 \mathrm{~cm}$ burial was 
equivalent to $63 \%$ burial intensity in respect to their height, and it was $57 \%$ for the 12-day-old seedlings (Table 1), showing that small differences in relative burial intensity cannot be the only factor resulting in the large physiological differences between the two seedling age groups.

Tolerance of dicotyledonous species to sand burial has been rarely experimentally assessed in dune building. Most dicotyledonous species tolerating burial have a clonal character like Honckenya peploides (IEvinsh, 2006). On the other hand, their cloneness can be induced by burial in the sand, like for Alyssum montanum subsp. gmelinii (SAMSONE et al., 2009). Plant clonality has been suggested as a factor that promotes burial tolerance and a high degree of clonal integration, and at extreme sand accumulation rates, it further promotes plant survival (CHEN et al., 2010). This is especially pronounced for different dune-building grasses, with positive growth response to sand burial both at the level of both underground rhizomes and leaf internodes (REIJERs et al., 2020). Tragopogon spp. did not display any clonal characteristics, and elongation of leaf bases was the only possible mechanism for these plants with typical rosette-forming shoot architecture. Other dicotyledonous species like Honckenya peploides show a high tolerance for burial under natural conditions, but the tolerance for gradual sand accretion of seedlings under controlled conditions was relatively low (GAGNÉ $\&$ Houle, 2002). This confirms the importance of life stages and an age-oriented experimental approach in sand burial studies of dune plants.

Age-associated differences in burial responses between the two species could be related to the fact that leaves of $T$. pratense lost elongation competence earlier than leaves of $T$. heterospermus (compare height changes for control plants of equal age of T. heterospermus in Fig. 1C \& D and these of T. pratensis in Fig. 3A \& B). It seems that the leaf elongation response of the 64-day-old $T$. heterospermus plants depended on a specific induction process, possibly, at the level of dedifferentiation, as it took almost 20 days to notice the first signs of accelerated leaf elongation in buried plants (Fig. 1D). Still, no such response occurred in T. pratensis (Fig. 3B). In contrast, the elongation response of actively growing leaves (12-day-old seedlings) started immediately after burial (Fig 1B) or within a few days after burial for the 36-days-old plants (Fig. 1C). However, leaf elongation of the 36-day-old T. pratensis plants was evident only ten days after the start of the treatment (Fig. 4A).

It seems that more extended period of preserving tissue elongation competence at leaf bases of T. heterospermus compared to T. pratensis acts as a significant component of tolerance to the moderate burial of the former. Also, the physiological ability to reallocate resources to shoot was seen for T. heterospermus (Fig. 2), but not for T. pratensis (Fig. 4). This mechanism has also been demonstrated for other species tolerant to sand burial (MAUN, 1998). However, even for burial-tolerant primary sand dune coloniser species such as Sporobolus virginicus, the elongation of internodes of buried shoots was not accompanied by a decrease in root to shoot ratio (FrosinI et al., 2012). Consequently, the absence of resource reallocation to shoots does not necessarily indicate lower burial tolerance. Despite being suggested as species not tolerant to sand burial (URBONIENE et al., 2015), T. heterospermus in the present study showed good ability to withstand the relatively moderate intensity of sand accretion without negative consequences for shoot growth. While higher sensitivity was evident at early seedling stages, established plants could tolerate $24 \%$ sand burial intensity relative to plant height, showing increased shoot growth by more than $100 \%$ and resource allocation from roots (Fig. 2). In contrast, dry meadow species $T$. pratensis, with no apparent adaptation to shifting sand conditions, showed a maximum increase of shoot biomass only by $35 \%$ (Fig. 4).

In conclusion, taxonomically related species $T$. heterospermus and T. pratensis share some standard level of general sand burial tolerance, which is considered elongation of leaf bases of adult plants in conditions of moderate sand burial. Still, only dune-adapted $T$. heterospermus plants exhibit efficient resource allocation from roots to shoots with increased intensity of sand accumulation. Moreover, T. heterospermus plants longer maintain competence to respond to sand burial in the form of growth stimulation compared to $T$. pratensis plants. T. heterospermus plants exhibit pronounced age dependence of burial tolerance, with high sensitivity to sand burial at the early seedling stage due to small shoot height and, possibly, physiological factors. 


\section{ACKNOWLEDGEMENTS}

The study was supported by the University of Latvia project "Functional diversity of ecosystems and their contribution to ecosystem services II" (UL No. ZD2016/AZ103).

\section{REFERENCES}

Chen J.-S., Lei N.-F., Dong M., 2010: Clonal integration improves the tolerance of Carex praeclara to sand burial by compensatory response. - Acta Oecologica, 36: 23-28.

Dech J.P., MaUn M.A., 2005: Zonation of vegetation along a burial gradient on the leeward slopes of Lake Huron sand dunes. - Canadian Journal of Botany, 83: 227-236.

Del Vecchio S., Fantinato E., Janssen J.A.M., BIoret F., Acosta A., Prisco I., Tzonev R., Marcenò C., Rodwell J., Buffa G., 2017: Biogeographic variability of coastal perennial grasslands at the European scale. - Applied Vegetation Science, 21: 312-321.

Di M., Upadhyaya M.K., 1993: Seed germination ecophysiology of meadow salsify (Tragopogon pratensis) and western salsify (T. dubius). - Weed Science, 41: 362-368.

Druva-Lusite I., IEvinsh G., 2010: Diversity of arbuscular mycorrhizal symbiosis in plants from coastal habitats. - Environmental and Experimental Biology, 8: 17-34.

Frosini S., Lardicci C., Balestri E., 2012: Global change and response of coastal dune plants to the combined effects of increased sand accretion (burial) and nutrient availability. - PLoS ONE, 7: e47561.

Gagné J.-M., Houle G., 2002: Factors responsible for Honckenya peploides (Caryophyllaceae) and Leymus mollis (Poaceae) spatial segregation on subarctic coastal dunes. - American Journal of Botany, 89: 479-485.

Gilbert M.E., Ripley B.S., 2008: Biomass reallocation and the mobilization of leaf resources support dune plant growth after sand burial. - Physiologia Plantarum, 134: 464-472.

Gilbert M.E., Ripley B.S., 2010: Resolving the differences in plant burial responses. -Austral Ecology, 35: 53-59.
Gormally C.L., Donovan L.A., 2010.: Responses of Uniola paniculata L. (Poaceae), an essential dune-building grass, to complex changing environmental gradients on the coastal dunes. - Estuaries Coasts, 33: 1237-1246.

HESP P.A., 1991: Ecological processes and plant adaptations on coastal dunes. - Journal of Arid Environments, 21: 165-191.

IEvinsh G., 2006: Biological basis of biological diversity: physiological adaptations of plants to heterogeneous habitats along a sea coast. - Acta Universitatis Latviensis, 710: 53-79.

ISERMANN M., 2011: Patterns of species diversity during succession of coastal dunes. - Journal of Coastal Research, 27: 661-671.

Jorritsma-Wienk L.D., Ameloot E., LensSen J.P.M., de KROON H., 2007: Differential responses of germination and seedling establishment in populations of Tragopogon pratensis (Asteraceae). Plant Biology, 9: 109-115.

Keijsers J.G.S., De Groot A.V., Riksen M.J.P.M., 2015: Vegetation and sedimentation on coastal foredunes. - Geomorphology, 228: 723-734.

Kent M., Owen N.W., Dale M.P., 2005: Photosynthetic responses of plant communities to sand burial on the machair dune systems of the Outer Nebrides, Scotland. - Annals of Botany, 95: 869-877.

LAime B., 2013: 2120 Shifting dunes along the shoreline with Ammophila arenaria (white dunes). In: Auniņ̌s A. (ed.), European Union Protected Habitats in Latvia. Interpretation Manual: 7375. - Riga.

Lee J.A., Ignaciuk R., 1985: The physiological ecology of strandline plants. - Vegetatio, 62: 319326.

Li S.-L., Warger M.J.A., Zuidema P.A., Yu F.-H., Dong M., 2010: Seedlings of the semi-shrub Artemisia ordosica are resistant to moderate wind denudation and sand burial in $\mathrm{Mu}$ Us sandland, China. - Trees, 24: 515-521.

MAUn M.A., 1994: Adaptations enhancing survival and establishment of seedlings on coastal dune systems. - Vegetatio, 111: 59-70.

MAUn M.A., 1998: Adaptations of plants to burial in coastal sand dunes. - Canadian Journal of Botany, 76: 713-738.

Maun M.A., Perumal J., 1999: Zonation of vegeta- 
tion on lacustrine coastal dunes: effects of burial by sand. - Ecology Letters, 2: 14-18.

Mavrodiev E.V., Soltis P.S., Soltis D.E., 2008: Putative parentage of six Old World polyploids in Tragopogon L. (Asteraceae: Scorzonerinae) based on ITS, ETS, and plastic sequence data. Taxon, 57: 1215-1232.

Qi M., Upadhyaya M.K., TuRkington R., 1996: Reproductive behaviour of natural populations of meadow salsify (Tragopogon pratensis). - Weed Science, 44: 68-73.

Qu H., Zhao H.-L., Zhao X.-Y., Zuo X.-A., WANG S.-K., CHEN M., 2017: Effects of sand burial on the survival and growth of two shrubs dominant in different habitats of northern China. - Environmental Monitoring and Assessment, 189: 149.

ReiJers V.C., Lammers C., DE Rond A.J.A., HoetJes S.C.S., LAMERs L.P., van der Heide T., 2020: Resilience of beach grasses along a biogeomorphic successive gradient: resource availability vs. clonal integration. - Oecologia, 192: 201-212.
Rériha I., 2013: 1230 Vegetated sea cliffs of the Atlantic and Baltic coasts. - In: Auninsš A. (ed.), European Union Protected Habitats in Latvia. Interpretation Manual: 48-51. - Riga.

RūsIṆA S., 2013: 6510 Lowland hay meadows (Alopecurus pratensis, Sanguisorba officinalis). - In: Auninsš A. (ed.), European Union Protected Habitats in Latvia. Interpretation Manual: 194-197. Riga.

Samsone I., Druva-Lūsīte I., Andersone U., NeČaJeVA J., Karlsons A., IEvinsh G., 2009: Plasticity of a dune plant Alyssum gmelinii in response to sand burial in natural conditions. - Acta Universitatis Latviensis, 763: 125-136.

Sykes M.T., Wilson J.B., 1990: An experimental investigation into the response of New Zealand sand dune species to different depth of burial by sand. - Acta Botanica Neerlandica, 39: 171-181.

Urbonienė R., Kelpšaitė L., BorisenKo I., 2015: Vegetation impact on the dune stability and formation on the Lithuanian coast of the Baltic Sea. - Journal of Environmental Engineering and Landscape Management, 23: 230-239.

\section{DVIEJŲ TRAGOPOGON RŪŠIŲ IŠ SKIRTINGŲ BUVEINIŲ AUGIMO ATSAKO İ PANARDI- NIMĄ SMĖLYJE PALYGINIMAS}

\section{Gederts IEVINSH, Kristīne K. LEJNIECE}

\section{Santrauka}

Vèjo sukeltas smèlio judèjimas yra esminis pakrančių smėlynų aplinkos veiksnys šiose buveinėse augantiems augalams. Šiame tyrime buvo palygintas dviejų retų rūšių, Tragopogon heterospermus, augančios pakrančių kopose ir pievinès rūšies Tragopogon pratensis, augimo atsakas ị jų panardinimą smèlyje. Natūraliose buveinèse surinktos séklos buvo pasètos automatizuotame šiltnamyje, o išauginti skirtingo amžiaus daigai buvo panardinti ị smèlị skirtinguose gyliuose. Abiejų rūšių augalų lapų pagrindų pailgèjimas smèlyje vidutiniame gylyje buvo vertinamas kaip jų tolerancija panardinimui smèlyje. Tačiau tik kopose augančių $T$. heterospermus augalų masė tolygiai pasiskirstė nuo šaknų iki ūglių galo, taip padidindama jų atsparumą panardinimui smėlyje. Nustatyta, $\operatorname{kad} T$. heterospermus atsparumas panardinimui į smèli reikšmingai priklausė nuo jų amžiaus, ankstyvose augimo stadijose augalų atsparumas buvo žymiai mažesnis. Apibendrinant galima teigti, kad nors abi tirtos augalu rūšys parode teigiamą ūglių augimo atsaką ị vidutinio intensyvumo panardinimą smèlyje, tačiau jų kilmè iš skirtingų buveinių lėmé skirtingą jų prisitaikymą. 